\title{
Necrosis and massive perforation of the small intestine in the course of lymphoma: a case report
}

\author{
Martwica i rozległe przedziurawienie jelita krętego w przebiegu chtoniaka złośliwego: \\ opis przypadku
}

\author{
Andrzej Żyluk ${ }^{\bowtie}$, Wojciech Jagielski, Agnieszka Mazur-Grzesiuk
}

Pomorski Uniwersytet Medyczny w Szczecinie, Klinika Chirurgii Ogólnej i Chirurgii Ręki, ul. Unii Lubelskiej 1, 71-252 Szczecin

Pomeranian Medical University in Szczecin, Department of General and Hand Surgery

$\bowtie$ azyluk@hotmail.com

\begin{abstract}
Necrosis and perforation of the small intestine of non-vascular origin are uncommon. Single cases have been described occurring in patients with blood and lymphatic malignant neoplasms. We present the case of necrosis and massive perforation of part of the small intestine in a patient diagnosed with diffuse large B-cell lymphoma (DLBCL), prior to commencement of therapy. At admission, the patient had typical symptoms and signs of a diffused peritonitis. Intraoperatively, faecal content was found
\end{abstract}

in the peritoneal cavity and necrosis with a massive perforation of approximately $10 \mathrm{~cm}$ of the terminal ileum. Resection of the involved fragment of intestine was performed, followed by closing of the distal stump of the ileum and end ileostomy. The post-operative course was uneventful and the patient was moved to the haematologic department for further treatment of the lymphoma.

Keywords: small bowel perforation; malignant lymphoma; peritonitis.

\begin{abstract}
ABSTRAKT
Martwica i przedziurawienie jelita cienkiego z przyczyn innych niż naczyniowe należą do rzadkości. Opisywano pojedyncze przypadki przedziurawień u pacjentów z nowotworami złośliwymi krwi i układu chłonnego. W pracy przedstawiono przypadek martwicy i rozpadu fragmentu jelita krętego, który wystąpił u chorej z rozpoznanym chłoniakiem rozlanym z dużych komórek B (DLBCL) przed rozpoczęciem leczenia. Przy przyjęciu pacjentka miała typowe objawy rozlanego zapalenia otrzewnej.
\end{abstract}

Śródoperacyjnie stwierdzono obecność treści kałowej w jamie otrzewnowej i martwicę jelita końcowego z ubytkiem ściany, na długości ok. $10 \mathrm{~cm}$. Zmieniony odcinek jelita resekowano, kikut dalszy zamknięto, a bliższy wyłoniono jako ileostomię końcową. Po operacji nie było powikłań i w 10. dobie chorą przekazano na oddział hematologii w celu leczenia chłoniaka.

Słowa kluczowe: przedziurawienie jelita cienkiego; chłoniak złośliwy; zapalenie otrzewnej.

\section{INTRODUCTION}

Necrosis and perforation of the small intestine of non-vascular origin are uncommon. Single cases of spontaneous perforations have been reported in the course of Leśniowski-Crohn disease, coeliac disease, presence of heterotopic gastric mucosa in the small intestine and Meckel diverticulum, as well as in patients with hematologic malignancies: leukaemia and lymphomas [1]. After the lymph nodes, the digestive tract is the second localization of malignant lymphomas, of which $1 / 3$ are present in the small intestine. In almost half of the cases, growing intestinal lymphatic tumours manifest with gastrointestinal bleeding or perforation, frequently preceding diagnosis of primary haematologic disease. These complications may also occur during preparation of a patient for, or in the course of, chemotherapy $[2,3,4]$. Literature provides descriptions of "classic" perforations, manifesting intraoperatively as a hole located in the intestine wall, in the lymphatic tumour involving the bowel, or at the site of tumour necrosis as a result of therapy. However, there are no reports of the disintegration of a relatively large fragment of the small intestine, occurring without a clearly determined cause. Such a case was found in a patient suffering from malignant lymphoma, occurring just prior to chemotherapy, and is reported in this article.

\section{CASE REPORT}

In November 2017, a 67-year-old female patient diagnosed with diffuse large B-cell lymphoma (DLBCL) was admitted to the Department of Haematology for chemotherapy. Although it was a scheduled admission, the doctor on call found that the patient's general condition was poor, with complaints of diffuse abdominal pain and weakness. An interview revealed 
that the disease had begun 2 days earlier with pain in middle hypogastrium, which had exacerbated gradually and had involved whole abdomen. A computed tomography (CT) scan of the abdomen had been performed a month prior to admission which showed pathological lymph node masses in the peritoneal cavity and retroperitoneal space, spreading over an area from the lesser curvature of the stomach to the minor pelvis. Additionally, the terminal $10 \mathrm{~cm}$ of the ileum was distended and thickened by $24 \mathrm{~mm}$ (Fig. 1).
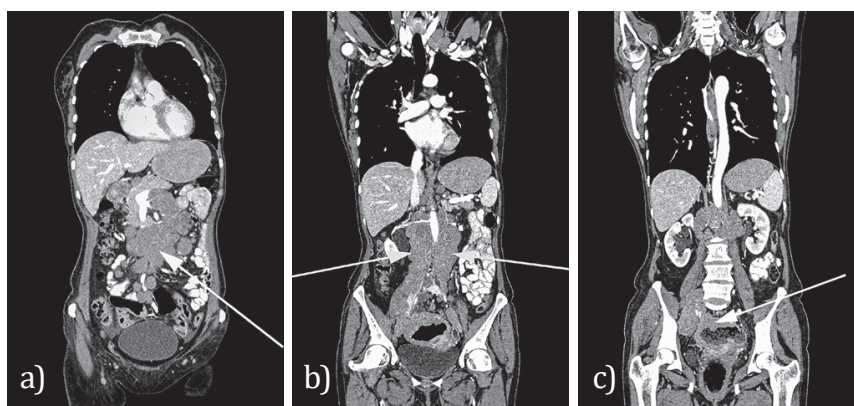

FIGURE 1. Abdominal CT scan performed a month prior to admission: a) lymph-node masses seen in the mesentery of the ileum (marked with an arrow); b) para-aortal lymph-node masses (marked with arrows); c) a loop of the terminal ileum with considerably thickened wall (marked with an arrow)

The patient had no fever and was not vomiting. At examination, the abdomen was distended, rigid, with apparent peritoneal signs (rebound tenderness, guarding, rigidity). Peristatic was lazy at auscultation. The patient declared last defecation 3 days before admission. Considering the high probability of perforation of the digestive tract, a nasogastric tube was introduced and $500 \mathrm{~mL}$ of thick dark fluid was aspirated. The patient was given plain abdominal X-ray which revealed the presence of a significant volume of gas in the peritoneal cavity (Fig. 2), confirming clinical suspicions of GI perforation. Biochemical tests showed highly elevated inflammatory parameters: concentration of C-reactive protein (CRP) $=560 \mathrm{mg} / \mathrm{dL}$, D-dimers $=4.1 \mathrm{mg} / \mathrm{L}$, procalcitonin $=36 \mathrm{ug} / \mathrm{L}$. Leukocyte count was $1.8 \mathrm{G} / \mathrm{L}$ (relatively low, but the patient was suffering from a lymphoma).

Considering the diagnosis of GI perforation and the serious clinical status, the decision for an emergency operation was made. After a short preparation - fluid and electrolyte

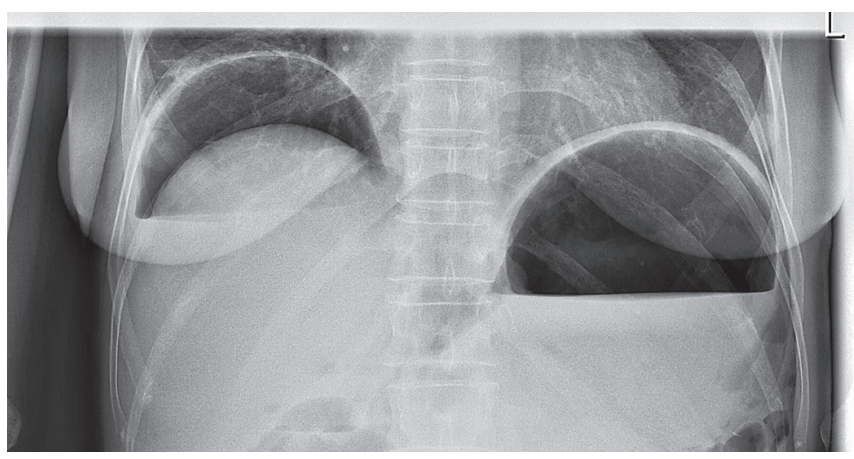

FIGURE 2. The plain abdominal X-ray performed at admission showing a great volume of gas in the peritoneal cavity replacement and antibiotic ( $1 \mathrm{~g}$ of cephazoline and $1 \mathrm{~g}$ of metronidazol) infusion, the patient was given surgery. As the direct cause of the perforation was obscure, the abdominal cavity was opened via midline incision in the middle abdomen. The great volume of gas discharged immediately after opening of the peritoneum, followed by turbid fluid and faecal contents. Exploration of the small intestine showed a large defect in the terminal intestine wall spreading over an area of $10 \mathrm{~cm}$ (Fig. 3). The margins of the defect were sharp-cut and rigid. The next proximal
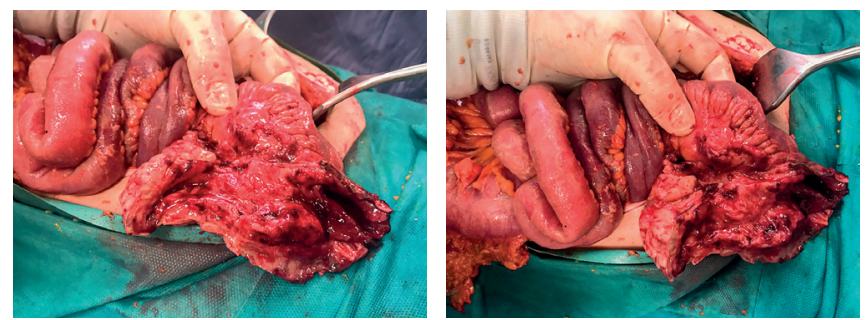

FIGURE 3. Intraoperative view of necrotic and perforated ileum

$20 \mathrm{~cm}$ of the small bowel showed signs of ischemia. After evacuation of the faeces and debridement of the peritoneal cavity, a $50 \mathrm{~cm}$ fragment of terminal ileum was resected followed by closure of the distal stump, approximately $5 \mathrm{~cm}$ from the caecum. The proximal stump was advanced as an end-ileostomy. After the operation, the patient was transferred to the Intensive Care Unit (ICU). An intensive fluid, anti-thrombotic and antibiotic therapy was commenced (Tazocin $3 \times 4.5$ g, wankomycin $2 \times 1 \mathrm{~g}$, metronidazol $3 \times 0.5 \mathrm{~g}$ and Diflucan $2 \times 0.2 \mathrm{~g}$ ) A bacterial culture showed infection with mixed organisms: E. coli, Enterobacter cloacae and species, Serratia spp., Providencia spp., Bacteroides vulg., sensitive to all the used antibiotics.

The postoperative course was unexpectedly favourable: the general condition of the patient improved and biochemical parameters of inflammation gradually reduced. At the $4^{\text {th }}$ postoperative day the patient was extubated, at the $5^{\text {th }}$ day the nasogastric tube was retrieved and oral feeding commenced. Drains from the peritoneal cavity were removed and the patient began walking. Six days after the operation the patient was discharged from ICU and returned to the surgical ward. Ileostomy discharged faecal contents, $800 \mathrm{~mL} /$ daily, in average. Ten days after the operation the patient was delivered to the Department of Haematology to fix further treatment of the basic disease (malignant lymphoma). In the instance of a favourable course of chemotherapy and obtaining a remission, reconstruction of the continuity of the digestive tract is intended. Histopathological examination of the resected ileum showed massive infiltration of the intestine wall with DLBCL. Four lymph-nodes infiltrated by the lymphoma were found in the mesentery.

The presented case is interesting for several reasons:

- the range of destruction of the small bowel, for which the term "perforation" seems to be inadequate ("massive perforation" sounds better). In all reported cases, the authors submit the classical perforations of the intestine, mostly within the lymphatic tumour, but not disintegration of a $10 \mathrm{~cm}$ fragment; 
- the impetuosity of the excessive necrosis and disintegration of the intestine wall, lasting approximately 2 days. Although the CT scan performed 1 month prior to the onset of the disease showed pathological changes in the ileum, they consisted of thickening of the wall, not of necrosis or perforation;

- the relatively good general condition of the patient at presentation, considering her 2 day history of faecal peritonitis.

The decision about surgical treatment and the type of surgery seems obvious. Although literature provides more reports on small bowel anastomosis after resection of a necrotic/perforated fragment, even in an infected peritoneal cavity, performance of a temporary end-ileostomy seems to be a much safer option $[4,5]$.

\section{DISCUSSION}

Vaidya et al., reported an analysis of GI perforations among 1 thousand patients with non-Hodgkin lymphomas treated in a single institution over 37 years (1975-2012). Ninety-two cases were identified (8.6\%), predominantly male (65\%) at an age of 64 years on average. The most common site of perforation was the small bowel - 54 cases ( $59 \%$ ), followed by the colon - 20 (22\%), and stomach - 15 (14\%). In half of the cases, the event (perforation) had preceded diagnosis of the lymphoma, while in the second half it occurred in patients with established diagnosis, in the course of chemotherapy. In $73 \%$ of cases, the perforation occurred within the tumour mass due to its necrosis, but in the remaining $27 \%$ it was caused by other mechanisms, i.e. acute colonic diverticulitis and bacterial or viral gastroenteritis. Twenty-eight of $92(30 \%)$ patients died in the peri-operative period [2].

Costa et al. reported an analysis of 14 cases of perforations of the small intestine in patients with non-Hodgins lymphomas treated in a single institution over a period of 5 years. Likewise to the previous paper, there was a predominance of men $(n=9,64 \%)$ at a mean age of 55 years. The perforation site was localised in the ileum in 13 cases, and in the jejunum in 1. Operative treatment included resection of the involved bowel fragment (usually with the tumour) and an anastomosis or end-ileostomy. Eight patients (57\%) died in the peri-operative period, 2 because of advanced basic disease and 6 owing to post-operative complications [6].

The relatively rare type of lymphoma enteropathy-associated T-cell lymphoma (EATCL) originates from intra-epithelial T-lymphocytes and may accompany coeliac disease. It is characterized by the occurrence of numerous ulcerations within the ileal wall and the tendency of bleeding and perforation [7].
Literature provides single case reports of spontaneous perforations of the small intestine in patients with various types of lymphomas, and a case of a simultaneous perforation of the ileum and colon in a patient with DLBCL $[4,5,8,9]$. One case of a preventive resection of a pathologically altered part of the ileum, prior to perforation occurrence is reported. In the patient with DLBCL, primarily involving the central nervous system, after effective chemotherapy and withdrawal central nervous system (CNS) changes, a new lymph-node manifestation of the malignancy in the abdomen occurred 3 years later. Ten days after commencement of aggressive chemotherapy, the patient started to complain of serious abdominal pain. An angio-CT scan revealed ischaemia of part of the ileum but without perforation. Chemotherapy was discontinued, and after a few days delay for growing an adequate white-cell count, the patient was given surgery. The ischaemic fragment of the bowel was resected followed by anastomosis of the stumps. The post-operative course was uneventful and after 2 weeks the discontinued chemotherapy was recommenced [10].

The authors did not find any case in literature similar to the case presented in this article and this fact prompted us to report it and sent it for publication.

\section{REFERENCES}

1. Freeman HJ. Spontaneous free perforation of the small intestine in adults. World J Gastroenterol 2014;20(29):9990-7.

2. Vaidya R, Habermann TM, Donohue JH, Ristow KM, Maurer MJ, Macon WR, et al. Bowel perforation in intestinal lymphoma: incidence and clinical features. Ann Oncol 2013;24(9):2439-43.

3. Abbott S, Nikolousis E, Badger I. Intestinal lymphoma-a review of the management of emergency presentations to the general surgeon. Int J Colorectal Dis 2015;30(2):151-7.

4. Veenstra M, van Unen JM, Strobbe LJ. Acute abdomen as the first presentation of a malignant lymphoma of the small intestine. Acta Chir Belg 2014;114(3):209-11.

5. Rehaman SA, Ramachandra CS, Jackaya RP. Primary gastro intestinal lymphoma presenting as perforation peritonitis. J Clin Diagn Res 2016;10(3):PD22-4.

6. Costa G, Lepre L, Tierno SM, Tomassini F, Frezza B, Fransvea P, et al. Emergency presentation of intestinal lymphoma. Ann Ital Chir 2012;83(5): 405-10.

7. Kim YS, Choi YS, Park JS, Kim BG, Cha SJ, Chi KC, et al. Case of small bowel perforation due to enteropathy-type T-cell lymphoma. Yonsei Med J 2009;50(6):859-61.

8. Nayak SR, Rao GB, Yerraguntla SS, Bodepudi S. Jejunal perforation: a rare presentation of Burkitt's lymphoma - successful management. Case Rep Oncol Med 2014;2014:538359.

9. Dughayli MS, Baidoun F, Lupovitch A. Synchronous perforation of nonHodgkin's lymphoma of the small intestine and colon: a case report. J Med Case Rep 2011;5:57.

10. Imataki O, Shiroshita K, Uchida S, Kida J, Akamoto S, Uemura M. Perforation in an intestinal malignant lymphoma case. BMC Res Notes 2016;9:308. 